\title{
O REALISMO NA LINGUAGEM LITERÁRIA
}

\author{
Hudinilson Urbano
}

Em "A atitude lingüística do falante"(1), Dino Preti conclui por uma não correspondência necessária entre a "competência" lingüística do falante (dialeto culto, comum ou popular) e o seus "desempenho" lingüístico, que dependerá dos graus de maior, média ou menor formalidade.

Se entendermos que a referida competência está comprometida com uma escala de valores sociais, "sendo possível associar imediatamente uma classe de maior prestígio sócio-econômico a uma linguagem culta; bem como uma classe operária ou toda uma população de baixa condição econômica a uma linguagem popular, com gradações que poderiam chegar até a um suposto dialeto vulgar." poderíamos interpretar que a regra seria uma correspondência entre a estratificação sócio-econômica e a lingüística, entendida esta tanto na competência quanto no desempenho lingüísticos do falante. Assim, uma pessoa sócio-economicamente mais elevada possuiria correspondentemente uma linguagem culta, e seu desempenho seria normalmente num registro formal. Dino Preti demonstrou que nem sempre os fatos ocorrem assim. Diríamos mesmo que, nos dias de hoje - quando um liberalismo de comportamento atinge até, ou principalmente, o comportamento lingüístico - dificilmente ocorrem dessa maneira.

Sem entrar na discussão das causas últimas dessa não coorrespondência - bem vislumbradas, aliás, pelo articulista - interessa-nos no momento fixarmo-nos na evidência dessa constatação, pondo-nos a considerar como se processa tal fenômeno e suas implicações na narrativa literária.

(1) - Dino Preti, "A atitude lingüística do falante" em $A$ gíria $e$ outros temas. São Paulo, T A. Queiroz-Edusp, pp. 69-77.

Língua e Literatura, (14), 1985. 
Partamos da observação óbvia de que as pessoas são capacitadamente cultas, incultas ou regularmente cultas - lingüisticamente falando - e que essa capacidade se deve a vários fatores. Por outro lado, social e frequientemente, essas pessoas se encontram nas mais diversas situações de formalidade ou informalidade. Essas situações é que determinam, dentro da competência lingüística do falante, o seu real desempenho lingüístico. O falante utilizará um registro formal, "constituído basicamente de estrutura e vocabulário do dialeto social culto" - se sua competência lingüística permitir "para as situações de maior formalidade" ou, um registro coloquial - preferimos informal — "formado a partir de um dialeto social popular" para as situações de menor formalidade. (2)

Por mais que procure elevar seu nível natural de desempenho, um falante inculto - lingüisticamente falando - não pode ou não consegue, numa situação ainda que formal, utilizar um dialeto social culto, que não possui e é incapaz de improvisar Essa é uma das razões a justificar o papel social da escola na tentativa de ampliar a competência lingüística do falante. $O$ contrário evidentemente pode ocorrer e ocorre com freqüência: uma pessoa de nível cultural elevado consegue com certa facilidade descer o seu nível lingüístico, com o propósito de atender a situações informais (nessas situaçōes, incluindo-se interlocutores incultos). Confira-se, por exemplo, o desempenho de um professor universitário numa classe inicial ou num diálogo com seu mecânico ou jardineiro.

Conclui-se daí que as situações de comunicação, que podem ser de maior, média ou menor formalidade, determinam, na medida do possível, um uso culto, comum ou popular de dialeto social. Donde, paralelamente, qualquer diálogo, embora diálogo, poder ser desenvolvido em linguagem culta, comum ou popular Em consequiência, coloquialismo culto, coloquialismo popular. Essa é a realidade da vida, decorrente da realidade que somos e das situações que vivemos.

Em outro artigo do mesmo livro, diz Dino Preti: "A linguagem da literatura não é um fato desligado do momento cultural em que surge." (3) Por outro lado, embora o processo de ficção não se confunda, "em momento algum, cam a realidade em si mesma, uma vez que, acima de tudo, é mimese e recriação dessa própria realida-

(2) - Id., pp. 69-70.

(3) - Dino Preti, "A língua oral e a literatura: cem anos de indecisão" em A gíria e outros temas. p. 193. 
de," (4) o princípio que norteia romancistas e contistas modernos é o do decalque mais próximo da realidade, nisso incluindo a realidade da língua falada. Sabe-se que uma reprodução pura e simples da língua falada é impraticável e anti-econônica, como esclarece a personagem de Graciliano Ramos, Paulo Honório, trazida à colação por Dino Preti:

"Esta conversa, é claro, não saiu de cabo a rabo como está no papel. Houve suspensões, repetições, mal-entendidos, incongruências, naturais quando a gente fala sem pensar que aquilo vai ser lido. Reproduzo o que julgo interessante. Suprimi diversas-passagens, moditiquei outras. O discurso que atirei ao mocinho do rubi, por exemplo, foi mais enérgico e mais extenso que as linhas chochas que aqui estão. É o processo que adoto: extraio dos acontecimentos algumas parcelas: o resto é bagaço. Ora vejam. Quando arrastei Costa Brito para - relógio oficial, apliquei-lhe uns quatro ou cinco palavrões obscenos. Esses palavrões, desnecessários porque não aumentaram nem diminuíram o valor das chicotadas, sumiram-se, conforme notará quem reler a cena da agressão, cena que expurgada dessas indecências, está descrita com bastante sobriedade." (5)

Sabe-se ainda, como lembra o ensaísta, que "A penetração da fala na prosa literária pode ocorrer de várias formas.": através do discurso indireto, do discurso indireto livre, do discurso direto, e, por último, da linguagem do narrador (6)

Neste último caso, trata-se da voz narrativa que ocorre ou na onisciência ficcional ou na ciência ficcional parcial, quando se trata de personagem-narrador A personagem-narrador é entidade complexa e atua ora como simples narrador, ora como simples personagem. Como personagem, deve falar segundo o nível sócio-cultural dessa personagem. Como narrador, manda a coerência ficcional que, embora narre de acordo com a formalidade compatível com a da estruturação narrativa, o faça nos limites da competência lingüística que o seu nível sócio-cultural permite.

Nessas condições, estamos frente a três níveis de competência (do escritor, do narrador, da personagem) e a duas situações de desempenho (de narração, de diálogo).

(4) - Id., p. 120.
(5) - Id., p. 120.
$(6)-$ Id., p. 104 
"Teoricamente, o escritor (. .) é o representante de uma camada cultural superior ( .). Conhece as normas e todas as possibilidades do sistema lingüístico e se sobrepõe, às vezes, a umas e outras,

" (7) Essa é a competência do escritor, cuja obtenção, e cujos limites, não importa aqui considerar.

"Normalmente, na onisciência ficcional, o nível do narrador é de linguagem culta, não havendo necessidade de outros artifícios que o destingam do nível teoricamente culto do escritor" (8) E que a figura do narrador onisciente - textual e lingüística porque lingüística e funcionalmente caracterizada no texto - se confunde, na leitura, com a do escritor - figura extratextual e extralingüística apesar de, na estrutura narrativa, serem entidades diferentes e autônomas. O narrador é um delegado do escritor e, uma vez investido dessa função e poder, exerce-os plenamente. E o caso do trecho bem representativo abaixo:

"Amadeu caminhou pelo meio das pilhas de garrafas empoeiradas até ao fundo do depósito, onde, sentado numa mesa, estava Joaquim. Eles, ainda meninos, haviam emigrado juntos e não se viam há cinco anos, desde que brigaram por motivo que Amadeu nem se lembrava mais. Mas de qualqıer forma estavam brigados, mesmo que Amadeu não soubesse porque. Mas Joaquim devia saber, e isso tornava ainda mais constrangedora a visita de Amadeu."

Nessa missão, de interferência e comunicação lingüística aparentemente neutras, revela-se um narrador culto, dentro do tradicional estilo narrativo literário. $\mathrm{Na}$ onisciência ficcional, portanto, dificilmente se poderá supor, a não ser em teoria, diferenças entre a linguagem do escritor e a do narrador Dino Preti refere-se ao caso do escritor Simões Lopes Neto, contista gaúcho, que, na introdução dos Contos gauchescos, apresenta um narrador, Blau, de nível sóciocultural diverso do dele, escritor. Na realidade, porém, trata-se de um artifício falso que não consegue descaracterizar a situação complexa de um narrador em primeira pessoa, portanto, narador-personagem, embora personagem periférica. Como tal, embora se possa até identificar suas narrativas como de onisciência ficcional, o narrador

(7) - Dino Preti, "Níveis linguíísticos do narrador literário" em A gíria e outros temas. p. 91.

(8) - Id., p. 93.

(9) - Rubem Fonseca, "O pedido" em Feliz ano novo. Rio de Ja neiro, Artenova, 1975, p. 87 
não é simplesmente narrador; é também personagem com tipo humano particularmente caracterizado, dotado de competência e desempenho lingüísticos próprios, independentes da competência e desempenho do escritor.

O narrador de primeira pessoa, porém, deve, coerentemente ter um desempenho de acordo com a sua competência lingüística, condicionada esta, por sua vez, ao nível sócio-cultural da personagem que ele encarna. Se de baixo nível, utilizará normalmente um dialeto social popular, porque mais não se pode pretender dele. Se de alto nível, contudo, pode ora usar o dialeto social culto, na enunciação narrativa, e ora, igual dialeto ou dialeto diverso, nas situações de fala como personagem. Se essas situações de fala forem de informalidade e de alto grau de emotividade, sua linguagem - a pretender-se uma atitude estética de reprodução da realidade - será vazada no dialeto social popular, podendo chegar até a um dialeto vulgar.

Rubem Fonseca é um dos escritores que melhor tem se apercebido dessa questão e demonstrado preocupação com esse enfoque. Observe-se o início do seu conto "Botando pra quebrar" em que o narrador em primeira pessoa possui a competência de um inculto marginal, colocado numa situação comunicativa de emocionado desafogo:

"Eu estava meio fudidão sem arranjar emprego e aporrinhado por estar nas costas de Mariazinha, que era costureira e defendia uma grana curta que mal dava pra ela e a filha. De noite nem tinha mais graça na cama, ela perguntando, arranjou alguma coisa? teve mais sorte hoje? e eu me lamentando que ninguém queria empregar um sujeito com a minha folha corrida; só malandro como o Porquinho que estava a fim de eu ir apanhar pra ele uma muamba na Bolívia, mas nessa transa eu podia entrar bem, era só os homens me patolarem de novo que eu pegava uns vinte anos. E o Porquinho respondia, se tu preferes ficar rufiando a costureira, o problema é teu. $O$ filho da puta não sabia como é que era lá dentro, nunca tendo ido em cana; foram cinco anos e quando eu pensava neles parecia que a vida inteira eu não tinha feito outra coisa, desde garotinho, senão ficar trancado no xadrez, e foi pensando nisso que eu deixei o Porquinho fazer pouco de mim na frente de dois bunda mole, morrendo de ódio e vergonha. E nesse mesmo dia, pra mal dos meus pecados, quando chego em casa a Mariazinha me diz que quer ter uma conversa séria comigo, que a garotinha precisava de um pai e que eu ficava sem aparecer em casa e a 
vida estava ruim e difícil, e que ela me pedia permissão para procurar outro homem, um trabalhador que ajudasse ela." (10)

A personagem-narrador vai nesse tom até o fim do seu relato, sucinto e rápido, cujos derradeiros acontecimentos narrados pode-se imaginar tenha ocorrido pouco tempo antes do próprio relato, o que explica a enfiada de frases apressadas, entremeadas a todo instante de expressões fáticas de irritado desabafo, como filho da puta (três vezes), porra e puta merda (cinco vezes), esta, inclusive, encerrando 0 relato.

Já, em "O outro", a personagem-narrador é um executivo, que, de acordo com o seu padrão sócio-cultural, narra num dialeto social culto, embora coloquial:

"Como todo executivo, eu passava as manhãs dando telefonemas, lendo memorandos, ditando cartas à minha secretária e me exasperando com problemas. Quando chegava a hora do almoço, eu havia trabalhado duramente. Mas eu sempre tinha a impressão de que não havia feito nada de útil." (11)

Mesmo quando fala como personagem e em situação de irritação, utiliza-se do mesmo dialeto:

"Não tenho que ajudá-lo coisa alguma, respondi."

Em "Fevereiro ou Março", temos um narrador de certa cultura e competência lingüística, a narrar num padrão se não totalmente culto, ao menos não totalmente popular:

"Fui procurar o Conde enquanto a Condessa tomava banho. Ele me perguntou muito delicado, mas direto, como quem quer ter uma conversa curta, onde eu ganhava o meu dinheiro. Eu expliquei para ele, também curto, que para viver não é preciso muito dinheiro; que o meu dinheiro eu ganhava aqui e ali." (13)

(10) - Rubem Fonseca, "Botando pra quebrar" em Feliz ano novo., p. 43 .

(11) - Rubem Fonseca, "O outro" em Feliz ano novo. p. 69

(12) - a) Id., p. 71.

b) Observe-se ainda a construção "Eu não queria mais ver aquele sujeito, que culpa eu tinha de ele ser pobre?" (Id., p. 71), onde de ele ser se conforma perfeitamente com o preciosismo gramatical.

(13) - Rubem Fonseca, "Fevereiro ou março" em Os prisioneiros. Rio de Janeiro, Codecri, 1978, p. 16. 
Em outro momento do mesmo conto, porém, aparece como personagem de baixo nível sócio-econômico, numa situação de explosão emocional, dirigindo-se a uma prostituta:

"Então eu disse para ela, agora você vai para casa, ouviu, se eu te encontrar zanzando por aí eu te quebro os cornos, entendeu? vou te seguir, se você não fizer o que eu estou mandando você vai se arrepender _-" (14)

Desaparece aí a linguagem tensa de padrão mais ou menos culto da voz narrativa, dando-se lugar ao vocabulário popular (zanzando), até vulgar (quebro os cornos); à inadequação gramatical (discordância no tratamento); às repetições temáticas (ouviu, entendeu?), às paráfrases. Mas o fizer (de feição culta), numa frase informal e emocional desse tipo, denuncia a competência mais culta do narrador

Tanto na linguagem utilitária quanto na linguagem literária, querendo esta ser decalque daquela, o princípio que preside o uso da linguagem é o da adequação à situaçãa, entendida esta como o conjunto de fatores do ato comunicativo: os interlocutores, o lugar e o tempo. Quanto mais adequada for a linguagem a esses fatores mais eficiente ela será e, portanto, mais recomendada. Se a linguagem literária quiser ser a reprodução da realidade falada eficiente, há de se adequar, como exemplarmente ocorre em Rubem Fonseca. 